\title{
Assessment of HPLC-FLD Method for Determination of Trastuzumab
}

\author{
Esra Engin $^{1}$, Ercüment Karasulu ${ }^{1,2}$, Hasan Ertaş ${ }^{1,3^{*}}$ (D) \\ ${ }^{1}$ Ege University, Research and Application Center of Drug Development and Pharmocokinetics, Bornova, İzmir \\ ${ }^{2}$ Ege University, Faculty of Pharmacy, Department of Biopharmaceutical Pharmacokinetics Technology, \\ Bornova, İzmir \\ ${ }^{3}$ Ege University, Faculty of Science, Department of Chemistry, Bornova, İzmir \\ Geliş / Received: 08/02/2019 Kabul / Accepted: 08/03/2019
}

\begin{abstract}
Trastuzumab $(150 \mathrm{kDa})$ is a monoclonal antibody (mAbs), which is directed against the human epidermal growth factor receptor-2 (HER2) and is used in patients with metastatic breast cancer treatment. In order to use these biosimilar drugs in therapy, bioequivalence studies should be performed and the success of these studies depends on the reliability of the analytical method. Present study describes a bioanalytical method for the total Trastuzumab determination using high-performance liquid chromatography (HPLC) coupled with fluorescence detection (FLD). Trastuzumab was isolated from rat serum using protein G column and eluted with glycine and then, the eluent was injected into HPLC system where the excitation and emission wavelengths were set at 278 and $343 \mathrm{~nm}$, respectively. Experimental parameters namely the flow rate, type of analytical column, type and composition of mobile phase, and the eluent used in sample preparation step were optimized by considering the peak resolution and recovery percentages. Under optimal conditions, a calibration graph was constructed and the detection limit was calculated as $5.3 \mu \mathrm{g} / \mathrm{mL}$. The applicability of the method for the pharmacokinetic studies was discussed.
\end{abstract}

Keywords: Trastuzumab, Monoclonal antibody, HPLC, Fluorescence Detector

\section{Trastuzumab Tayininde HPLC-FLD Yönteminin İncelenmesi}

$\ddot{O} \mathbf{z}$

Trastuzumab (150kDa), insan epidermal büyüme faktörü reseptörü-2'ye (HER2) karş1 yönlendirilen ve metastatik meme kanseri tedavisi gören hastalarda kullanılan bir monoklonal antikordur (mAb). Bu biyobenzer ilaçların tedavide kullanılabilmesi için biyoeşdeğerlik çalışmalarının yapılması gereklidir ve bu çalışmaların başarısı da analitik yöntemin güvenilirliğine bağlıdır. Bu çalışmada, fluoresans dedektörü (FLD) ile birleştirilmiş yüksek performanslı sıvı kromatografisi (HPLC) kullanarak toplam Trastuzumab analizi için bir biyoanalitik yöntem tanımlanmıştır. Trastuzumab, protein $G$ kolonu kullanılarak sıçan serumundan izole edildikten sonra glisinle elüe edilerek, elüent, uyarma ve emisyon dalga boylarının sırasılla 278 ve 343 nm'ye ayarlandığı HPLC sistemine enjekte edilmiştir. Akış hızı, kolon türü hareketli faz türü ve bileşimi ve örnek hazırlama aşamasında kullanılan elüent gibi deneysel parametreler, piklerin ayrılması ve geri kazanım yüzdeleri dikkate alınarak optimize edilmiştir. Optimum koşullar altında kalibrasyon grafiği oluşturulmuş ve belirtme alt sınırı $5.3 \mu \mathrm{g} / \mathrm{mL}$ olarak hesaplanmıştır. Bu yöntemin farmakokinetik çalışmalar için uygulanabilirliği tartışılmıştır.

Anahtar Kelimeler: Trastuzumab, Monoklonal antikor, HPLC, Fluoresans Dedektör

\section{Introduction}

Today, a number of companies in pharmaceutical industry focus on developing new drugs for therapeutic use. This industry is regulated by official agencies that control the side effects of the products (FDA, 2018).

Generic drugs are medicinal products that are structurally and therapeutically equivalent to an original product whose patent and/or data protection period has expired (WHO, 2009). The applications should be performed in the same way as the original drug, and their bioequivalence is tested by comparing the absorption rate or bioavailability of the innovator drug in healthy volunteers. On the other hand, a biosimilar product is regarded as a similar biologic but, not as a generic 
(Geigert, 2013). These biotherapeutics are obtained from live sources by using biotechnological methods (Nacak et al. 2012). Recent advances in bioengineering technologies have led the development of new strategies for producing biotherapeutics (Elgundi et al., 2017).

The most effective components of humoral immunity are antibodies synthesized by white blood cells in the bone marrow. These components belong to a family of globular proteins called immunoglobulins (Ig) and each antibody molecule contains identical two light and two heavy chains joined by disulphide (Selimoğlu et al, 2016).

The basic functions of an antibody are binding to antigens by their amino terminal ends of the light chains and an effector function along the carboxyl terminal end of the heavy chains (Merino et al, 2010). The most common Ig class used for biopharmaceutical monoclonal antibodies (mAbs) is immunoglobulin $\mathrm{G}$ (IgG) with a characteristic Y-shape.

Today, as medical research moves towards a new era of personalized therapy, the use of $\mathrm{mAbs}$ has emerged as the leading product in the biopharmaceutical market to treat a wide variety of diseases (Liu et al. 2014). The first $\mathrm{mAb}$ for clinical use was licensed 30 years ago, and since then, $30 \mathrm{mAbs}$ have received approval for clinical use. Today, there are more than 300 antibody-based products in clinical development in the world (Elgundi el al., 2017).

Cancer immunotherapy is one of the adjuvant methods of modern medicine for cancer treatment (Şakalar et al, 2013). Monoclonal antibodies are more commonly used in these therapies than vaccine and cellular therapy. There are at least 12 monoclonal antibodies currently approved for several types of cancers. Breast cancer is the most common cancer in women and its prevalence in our country has doubled in the last 20 years (Kurt et al., 2013).

In all breast cancer patients, the human epidermal growth factor receptor-2 (HER2) is over-expressed about 25\% (Öztop, 2007). Trastuzumab (Herceptin, Roche) is a humanized monoclonal immunoglobulin gamma 1 (IgG1) antibody targeting HER2. Trastuzumab inhibits proliferation and induces cell death via extracellular and intracellular mechanisms. The FDA first approved this mAb in 1998 and by the European Union Medicines Agency (EMEA) in 2000. Previously, Herceptin was used only in patients with metastatic breast cancer, but today it is registered for early breast cancer treatment (Damen et al, 2009, RXMediapharma $\left.{ }^{\circledR}, 2019\right)$.

The patents on Herceptin expired in Europe in 2014, and it will expire in the US in 2019. Pharmaceutical companies focus on developing biosimilar product of the original drugs with expired patent (www.gabionline.net). In order to use these biosimilar drugs in therapy, bioequivalence studies are necessary as regulated by the European Medicines Agency (EMA) in the EU (www.ema.europa.eu, 2010). Pharmacokinetic studies are the basis for clinical comparison studies between biosimilar medicinal products and reference medicinal products (www.titck.gov.tr). These studies should follow the recommended dosage range for the reference medicinal product and the route of administration. The relation between dose, plasma concentrations, and therapeutic or toxic effects should be evaluated.

The success of all these studies depends on the reliability of the analytical method to be developed. Literature Survey on the mAb analysis in biological matrices have revealed that early studies on mAbs analysis depend on immunoassays such as enzyme linked immunosorbent assays (ELISA) (Damen et 
al., 2009b), radioimmunoassay (Williams and Perry, 1985) and immunofluorescence (Rebello and Hale, 2002). Although immunoassays provide high sensitivity and high throughput, these methods are time consuming and require development of specific reagents (Park et al, 2015). It is not common to use immunoassays developed for preclinical studies to analyze clinical study samples due to the matrix specificity of the assay. Therefore, it is necessary to develop alternative techniques to confirm the values from ELISA.

Damen et al (2009b) reported a bioanalytical assay for Trastuzumab using highperformance liquid chromatography (HPLC) coupled with fluorescence detection (FLD) for the first time. Trastuzumab was isolated from human serum using protein $\mathrm{A}$ and protein $\mathrm{G}$ column along with sepharose coupled with anti-trastuzumab idiotype antibodies. The samples were then; injected onto a C8 column and the obtained results were found comparable with those obtained with ELISA.

Liquid chromatography coupled to tandem mass spectrometry with electrospray ionization interface (LC-ESI MS/MS) provides another alternative to ELISA than HPLC-FLD method (Park et al., 2015). The LC-MS/MS technique is suitable to detect the compounds up to $2000 \mathrm{~m} / \mathrm{z}$ ratio and considering that mAbs are typically $150 \mathrm{kDa}$, it is necessary to digest these big structures into much smaller peptide fragments prior to the analysis (Iwamoto et al., 2015). Efficient proteolytic digestion is critical for obtaining the peptides necessary for accurate quantification and trypsin is widely used for this purpose. However, the LC systems coupled with tandem MS detectors have several issues for complex matrices such as overload condition suppressing the ionization and the noise elevation from the excess peptide sample and trypsin content. Here, the sample preparation and isolation steps have the critical importance in terms of analytical accuracy and sensitivity.

For addressing this issue, a novel method called nano-surface and molecularorientation limited (nSMOL) proteolysis was introduced by Shimadzu (2017). This technique provides a selective proteolysis in the Fab region and by this means it is possible to reduce the formation of other peptides during digestion eliminating the interferent peptide population. However, these techniques are expensive and alternative simpler and cost effective methods are being searched.

Considering the increase in breast cancer in our country, the use of Trastuzumab will increase in the near future for the treatment. In the present study, an HPLC-FLD method coupled with protein $\mathrm{G}$ column prior to the detection was developed for the determination of Trastuzumab in serum samples. The assessment of the method was made by comparing the method characteristics with previous studies.

\section{Material and Method}

\subsection{Chemicals and biological materials}

Herceptin (150 mg, Roche, Basel, Switzerland) is ready to use has been supplied by Oncology department of Ege University Medical Faculty (Izmir, Turkey). The rat serum, were obtained by Biochemistry department in Science Faculty (Izmir, Turkey). Ege University Animal Experiment Ethics Committee has been approved for the research that Development and Application of LC-MS/MS Method for Determination of Monoclonal Antibodies (mAbs) In Vivo Matrix.(Ethical report no 2018-080).

Glycine (Biotechnology Grade) and Phosphate Buffered Saline (PBS Tablets) was purchased from BioShop (Burlington, Canada). Nab Protein G Spin columns 0.2 
$\mathrm{mL}$ that contains $0.02 \%$ sodium azide as a preservative, was purchased Thermo Fisher Scientific (Rockford, USA). Trifluoroacetic acid (TFA) was purchased from Merck (Darmstadt, Germany), isopropanol (IPA) from J.T. Baker (New Jersey, USA) and Acetonitrile (ACN) from Carlo Erba (Barcelona, Spain). Hydrochloric acid ( $\mathrm{HCl}$, 37\%) was bought from Sigma Aldrich (St. Louis, Missouri, USA). HPLC grade water was supplied from a USF Purelab and Millipore Elix \& Rios System combined Milli- Q Synthesis System, including UV radiation and ultrafiltration units.

\subsection{Apparatus}

The HPLC procedure was executed using was Shimadzu LC- 20 AT Pump A and Pump B, Shimadzu CBM-20A pump controller, a Shimadzu SIL- 20 AC HT autosampler, Shimadzu CTO- 10AS VP column oven and a Shimadzu RF 20A XS Fluorescence Detector (Shimadzu Corporation, Kyoto, Japan). Zorbax 300SBC8 $4.6 \quad$ x $100 \mathrm{~mm} \quad 3.5 \mu \mathrm{m} \quad$ (Agilent Technologies, Santa Clara, CA, USA) analytical column were used for the reversedphase technique at $75^{\circ} \mathrm{C}$. Mobile Phase A (MPA) contains $0.1 \%$ TFA in water and mobile phase B (MPB) contains $0.1 \%$ TFA in isopropanol (IPA)/ acetonitrile (ACN)/ water $(70: 20: 10 ; \quad \mathrm{v} / \mathrm{v} / \mathrm{v})$. The gradient program is as given in Table 1 with 0.5 $\mathrm{mL} / \mathrm{min}$ flow rate. Fluorescence detector was set at an excitation wavelength of $278 \mathrm{~nm}$ and an emission wavelength of $343 \mathrm{~nm}$ and LC Solution software was employed for qualitative and quantitative analysis. All samples were weighted by using analytical balance with a scale of 0.0001 (Denver Instrument, Germany). Centrifugation was performed with a micro centrifuge set at 5000 rpm (Sigma Aldrich, St. Louis, Missouri, USA).

\subsection{Preparation of calibration standards and solutions}

Ready to use PBS tablet was dissolved in 100 $\mathrm{mL}$ HPLC grade water and the $\mathrm{pH}$ was checked to maintain 7.00. The stock solutions $(1.00,0.10$ and $0.01 \mathrm{mg} / \mathrm{mL})$ of Herceptin were prepared by diluting the main stock solution $(21 \mathrm{mg} / \mathrm{mL})$ with the PBS and then, calibration standards of $5,10,20,40$, 60 , and $120 \mu \mathrm{g} / \mathrm{mL}$ were prepared by diluting with blank serum gone through the Protein $G$ column. The glycine solution $(0.1 \mathrm{M})$ used for the elution was prepared by dissolving $0.7507 \mathrm{~g}$ of glycine in $80.0 \mathrm{~mL}$ of HPLC grade water and then, adjusting the $\mathrm{pH}$ to 2.5 by addition of $\mathrm{HCl}$. The final volume was made $100 \mathrm{~mL}$ by adding pure water.

Table 1 Gradient program used for the HPLC-FLD determination of Trastuzumab

\begin{tabular}{|l|c|c|c|c|c|c|}
\hline MPA (\%) & 90 & 75 & 60 & 0 & 0 & 90 \\
\hline MPB (\%) & 10 & 25 & 40 & 100 & 100 & 10 \\
\hline $\begin{array}{l}\text { Time } \\
(\text { min) }\end{array}$ & 2 & 4 & 21 & 21 & 26 & 35.5 \\
\hline
\end{tabular}

\subsection{Isolation of Trastuzumab on to the Protein G column}

Protein $\mathrm{G}$ column was prepared by following the instructions by manufacturer (Thermo, 2013). This material includes $0.02 \%$ sodium azide in phosphate-buffered saline (PBS) solution for storage purposes. The mini column was centrifuged at $5000 \mathrm{rpm}$ for 1 min and after spiking $400 \mu \mathrm{L}$ PBS for equilibration, it was further centrifuged for 1 $\min$ to remove the storage solution as described elsewhere (Damen et al., 2009b).

A $200 \mu \mathrm{L}$ serum spiked with $40 \mu \mathrm{g} / \mathrm{mL}$ Trastuzumab was loaded on top of the column and the column was hand shaken for $10 \mathrm{~min}$. To remove the components other 
than the Trastuzumab, the column was rinsed with $200 \mu$ L PBS for three times. Finally, the Trastuzumab retained on the column was eluted in triplicate elution by using $400 \mu \mathrm{L}$ glycine in each time. The eluate and the solutions from the washing steps were injected into the HPLC-FLD system. The same procedure was also applied for the blank serum sample and all the solutions along with PBS spiked with $40 \mu \mathrm{g} / \mathrm{mL}$ trastuzumab were all analyzed to assess the extraction efficiency of the column. These steps were visualized in Figure1.

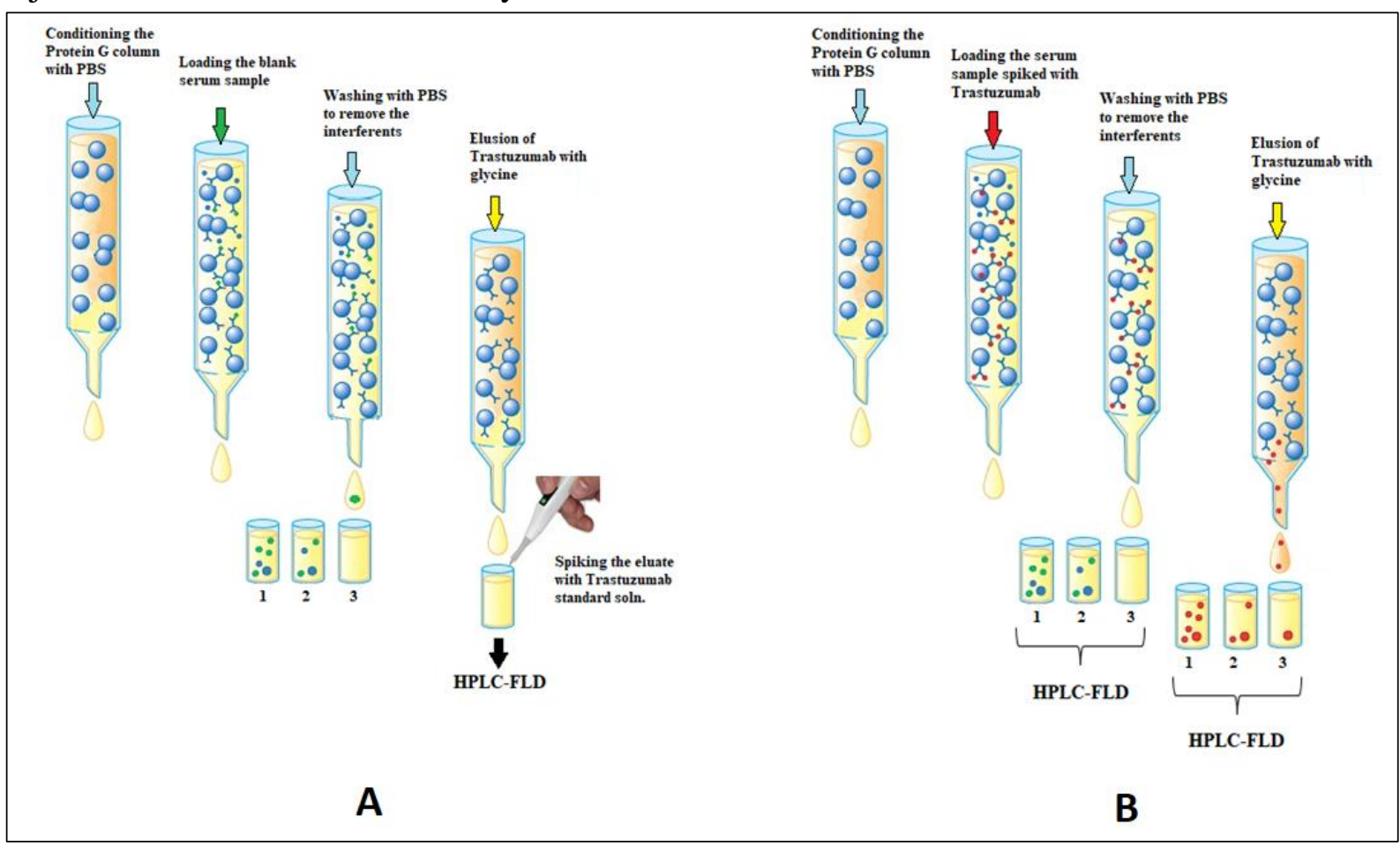

Figure 1. A) Preparation of Trastuzumab calibration standards after isolation of blank serum samples by Protein G column, B) The steps in spiked serum sample preparation for HPLC-FLD method.

\section{Results and Discussion}

Initial studies include the HPLC-FLD analysis of trastuzumab in serum samples by comparing the results with the literature. The serum samples eluted from Protein $G$ column as shown in Figure 1A was injected into the HPLC system having C8 column at a flow rate of $0.5 \mathrm{~mL} / \mathrm{min}$. The gradient program given in Table 1 was applied. The excitation wavelength of the fluorescence detector was set at $278 \mathrm{~nm}$ while the emission was measured at $343 \mathrm{~nm}$.

The calibration graphs were plotted between concentrations of trastuzumab against peak area obtained through FL detection. The calibration curve was constructed by using the blank serum sample loaded onto the previously conditioned Protein G column and the column was then, washed with PBS in triplicate. Elution was made with glycine solution as described earlier and then the eluate was spiked with Trastuzumab standard solution to give $5.0,10.0,20.0,40.0,60.0$ and $120.0 \mu \mathrm{g} / \mathrm{mL}$ solutions as described in Figure 1. These solutions were injected into the HPLC system and gradient elution was applied as given above. The response of FLD was recorded against time and the chromatogram recorded with samples spiked with standards to be $120 \mu \mathrm{g} / \mathrm{mL}$ was given in Figure 2. 


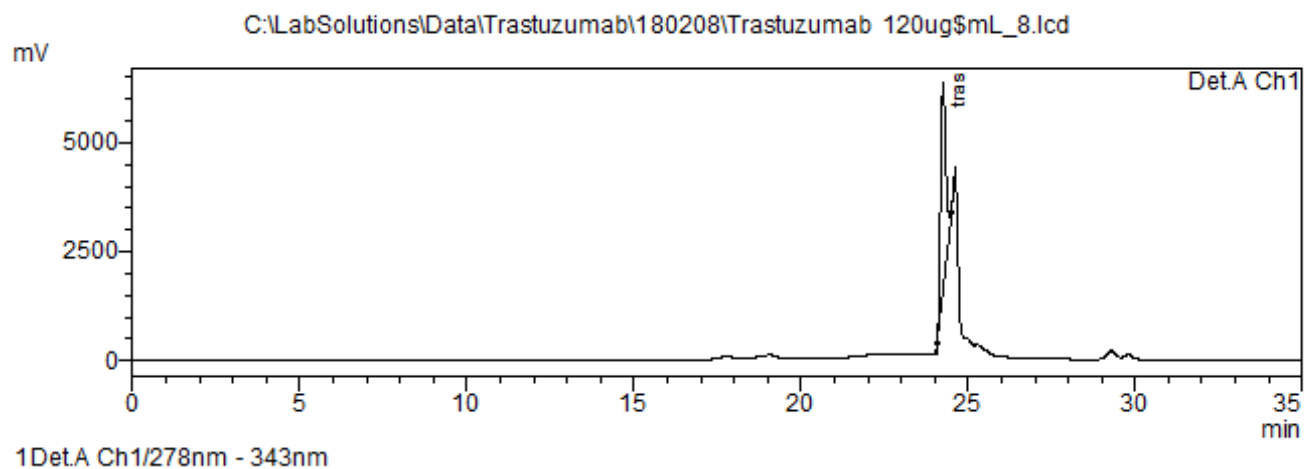

Figure 2. HPLC-FLD Chromatograms of eluate after purification using Protein G column and spiked with 120 $\mu \mathrm{g} / \mathrm{mL}$ Trastuzumab. The retention time of is $24.2 \mathrm{~min}$.

As can be seen from the chromatogram, multiple peaks appear at around $24^{\text {th }}$ min and since the peak is poorly separated, total peak area under the curve was taken into account for the integration. The calibration curve was constructed by plotting the total peak area against the spiked Trastuzumab concentrations. The dynamic range of calibration curve was very good $(\mathrm{R}=0.999)$ in the range of 5.0 to $120 \mu \mathrm{g} / \mathrm{mL}$ with an equation of $y=416641 x-427172$. Apart from this, for the quantitation of trastuzumab with high accuracy and repeatability, this range should be included covering the limit of quantitation (LOQ) level of the standard solution. The deviations from the calibration values for the accuracy in the calibration curve were also calculated and given in Table 2. The limit of detection (LOD), was estimated on the basis of 3.3 times of error in the regression line $(\mathrm{Sy} / \mathrm{x})$ divided by slope obtained the calibration curve whereas the LOQ was based on 10 times the error in the regression line divided by slope obtained from the calibration curve. The error in the regression line was calculated by using "Linest" command through in Excel sheet. By this means, the LOD and LOQ was found $5.3 \mu \mathrm{g} / \mathrm{mL}$ and $16.1 \mu \mathrm{g} / \mathrm{mL}$, respectively.
Table 2. Deviations from the calibration curve values of Trastuzumab

\begin{tabular}{|c|c|c|}
\hline $\begin{array}{c}\text { Spiked Conc. } \\
(\boldsymbol{\mu g} / \mathbf{m L})\end{array}$ & $\begin{array}{c}\text { Obtained Conc. } \\
(\boldsymbol{\mu g} / \mathbf{m L})\end{array}$ & Deviation $(\%)$ \\
\hline 5.0 & 4.1 & -18.0 \\
\hline 10.0 & 8.5 & -15.0 \\
\hline 20.0 & 21.0 & 5.0 \\
\hline 40.0 & 42.4 & 6.0 \\
\hline 60.0 & 59.6 & -0.6 \\
\hline 120.0 & 119.4 & -0.5 \\
\hline
\end{tabular}

According to EMA validation guide, the criteria is established as the deviation at LLOQ level should be in the range of $\pm 20 \%$ and at other concentration levels this figure should be kept in the range of $\pm 15 \%$. According to these criteria, the deviations calculated for the calibration graph was found to be acceptable. 
The next step includes the studies with the serum samples spiked with $40 \mu \mathrm{g} / \mathrm{mL}$ Trastuzumab loaded onto the protein $G$ column as schematically described in Figure 1B. This concentration was chosen as the medium level of the calibration studies. The chromatogram obtained after elution with glycine solution has displayed multiple peaks indicating the poor selectivity of the method in accordance with the previous report (Damen et al., 2009b). The additional peaks in the chromatogram might be resulted from the other components of the serum sample. In order to improve the selectivity, experimental parameters were optimized. First, the flow rate was increased to $1.0 \mathrm{~mL} / \mathrm{min}$ while the gradient program was changed to shorten the analysis time to $15 \mathrm{~min}$. The chromatograms for blank serum sample and spiked with Trastuzumab to be 60 and $120 \mu \mathrm{g} / \mathrm{mL}$ were recorded (data not shown). Detailed inspection of these chromatograms have revealed that even after passing blank serum sample through the Protein G column and eluting with glycine solution, multiple peaks around $2^{\text {nd }}$ min. A large peak at around 10 min for the blank sample was observed, which was grown proportionally upon addition of $60 \mu \mathrm{g} / \mathrm{mL}$ and $120 \mu \mathrm{g} / \mathrm{mL}$ Trastuzumab into the serum sample prior to the column separation. In order to eliminate the peaks commencing at $2^{\text {nd }} \mathrm{min}$, the elution time further increased to $35 \mathrm{~min}$ with a flow rate of $1.0 \mathrm{~mL} / \mathrm{min}$ however, no significant improvement was obtained.

Alternatively, isocratic elution (MPA/MPB: 60/40) was used but, no satisfactory results were obtained. Other attempts such as using aqueous $0.1 \%$ Formic acid (FA) solution as the mobile phase $\mathrm{A}$ and use of Zorbax Eclipse XDB-C18 column $(4.6$ x $100 \mathrm{~mm} 5$ $\mu \mathrm{m})$ was also failed.

Finally, the eluent type in the sample preparation step was changed to PBS different from the literature (Damen et al., 2009b). The gradient program given in Table 1 was applied with a flow rate of 1.0 $\mathrm{mL} / \mathrm{min}$. Detailed inspection of the chromatograms obtained have revealed that the peak at $2^{\text {nd }}$ minute was observed for the spiked sample and the peak at tenth minute was increased upon spiking the serum sample with the $120 \mu \mathrm{g} / \mathrm{mL}$ of Trastuzumab. The comparison of the performances of the eluents can be seen in Figure 3. As can be deduced from the peak area values given inset, glycine is far from being efficient in the elution of the Trastuzumab and better sensitivity and selectivity can be obtained with PBS eluent.

The recovery values were calculated for both series of experiment and the results were summarized in Table 3. As can be concluded from the table, the eluates obtained after passing through the column, the mean recovery of two parallel studies was calculated as about $21.5 \%$ while the PBS has given recovery values more than hundred percent. Interestingly, PBS has provided a better elution performance than that of the glycine solution, different from the former study (Damen et al., 2009b).

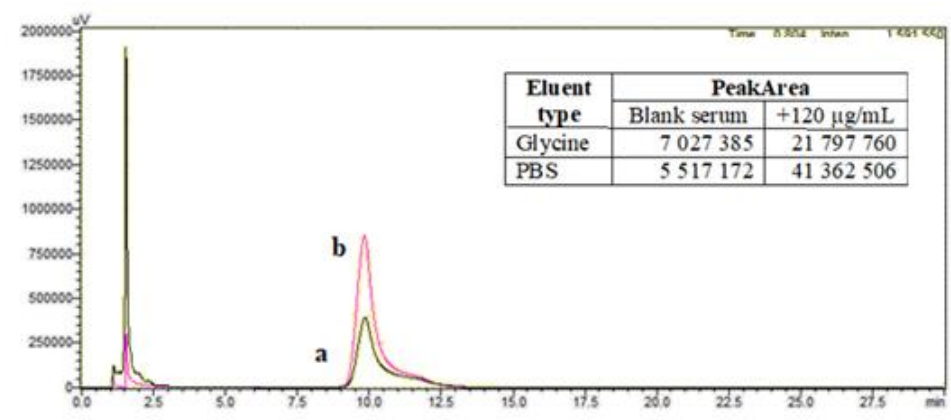


Figure 3. HPLC-FLD chromatograms obtained for $120 \mu \mathrm{g} / \mathrm{mL}$ Trastuzumab spiked serum sample passed through the Protein G column and then, eluted with a) glycine and b) PBS under gradient conditions given in Table 1. The peak area values were given inset.

Table 3 The recovery studies carried out with $40 \mu \mathrm{g} / \mathrm{mL}$ Trastuzumab after elution with PBS and Glycine solutions

\begin{tabular}{|c|c|c|c|c|}
\hline \multirow{2}{*}{ Recovery } & \multicolumn{2}{|c|}{ Elution with PBS } & \multicolumn{2}{c|}{ Elution with Glycine } \\
\cline { 2 - 5 } & Found $(\boldsymbol{\mu g} / \mathbf{m L})$ & \% Recovery & Found $(\boldsymbol{\mu g} / \mathbf{m L})$ & \% Recovery \\
\hline $\mathbf{X}_{\mathbf{1}}$ & 43,40 & 108,51 & 8,79 & 21,97 \\
\hline $\mathbf{X}_{\mathbf{2}}$ & 42,73 & 106,83 & 8,40 & 21,01 \\
\hline Average & 43,07 & 107,67 & 8,60 & 21,49 \\
\hline SD (N=3) & 0,48 & - & 0,27 & - \\
\hline RSD\% & 1,11 & - & 3,15 & - \\
\hline Deviation\% & 7,67 & - & $-78,51$ & \\
\hline
\end{tabular}

\section{Conclusion}

For the quantification of Trastuzumab in biological matrices, analytical techniques, which could be an alternative to ELISA, are being searched. Present study deals with a HPLC-FLD method for the detection of total Trastuzumab in rat serum. Trastuzumab was isolated from rat serum using protein $G$ column and the calibration curve was constructed by using total peak area. Although the linearity was excellent ( $\mathrm{R}=$ 0.999 ) in the range of 5.0 to $120 \mu \mathrm{g} / \mathrm{mL}$ concentration levels, optimization studies were necessary to improve the peak resolution. The influence of the experimental parameters on the peak area and its shape were investigated and then, the eluent used in sample preparation step was changed as PBS since better recovery values were obtained.

Overall results indicate that HPLC-FLD can provide an alternative to ELISA for the bioanalysis of trastuzumab. However, multiple peak formation and poor resolution limits the selectivity of the method. In addition, the run time is relatively high and therefore, further studies will include the use of LC-MS/MS methods for Trastuzumab analysis.

\section{Acknowledgements}

This work was supported from Ege University Research and Application Center of Drug Development and Pharmacokinetics. Authors would like to thank Ege University Faculty of Science, Department of Biochemistry for supplying rat serum. E. Engin would like to thank TÜBİTAK for 2211-A General Domestic Doctorate Scholarship Program.

\section{References}

Damen et al., 2009a. Development and validation of an enzyme-linked immunosorbent assay for the quantification of trastuzumab in human serum and plasma, Damen, C.W.N., de 
Groot, E.R., Heij, M., Boss, D.S., Schellens, J.H.M., Rosing, H., Beijnen, J.H., Aarden, L.A., Analytical Biochemistry, 391, 114-120

Damen et al., 2009b. The bioanalysis of the monoclonal antibody trastuzumab by high-performance liquid chromatography with fluorescence detection after immuno-affinity mpurification from human serum, Damen, C.W.N., Derissena, E.J.B., Schellensb, J.H.M., Rosinga, H., Beijnena, J.H., Journal of Pharmaceutical and Biomedical Analysis, 50, 861-866.

Elgundi et al., 2017. The state-of-play and future of antibody therapeutics, Elgundi, Z., Reslan, M., Cruz, E., Sifniotis, V., Kayser, V., Advanced Drug Delivery Reviews, 122, 2-19

FDA, 2018. https://www.usa.gov/federalagencies/food-and-drug-administration Access date: 13.12.2018

Geigert, 2013. Biologics Are Not Chemical Drugs, The Challenge of CMC Regulatory Compliance for Biopharmaceuticals and Other Biologics, J. Geigert, Springer Science+Business Media New York

Iwamoto et al., 2015. The development of the validated LCMS bioanalysis of trastuzumab in human plasma using a selective detection method for complementarity determining regions of monoclonal antibodies: nano-surface and molecular-orientation limited (nSMOL) proteolysis, Iwamoto, N., Yamane, N., Umino, Y., Hamada, A., Shimada, T., Anal. Methods, 2015, 7, 9177

Kurt et al., 2013. Complementary/alternative therapies in patients with breast cancer, Kurt, H., Keskek, Ş.Ö., Cil, T.,
Canataroglu, A., Turkish Journal of Oncology, 28(1):10-15

Liu, 2014. The history of monoclonal antibody development - Progress, remaining challenges and future innovations, Liu, J.K.H., Annals of Medicine and Surgery, 3, 113-116

Merino et al., 2011. Monoclonal antibodies. Basic features, Merino, A.G., Neurología. 26(5):301-306

Nacak et al., 2012. Biosimilar Drugs, Nacak, M., Sezer, Z., Erenmemişoğlu, A., Clin Anal Med; 3(2): 251-256

Öztop, 2007. The Use of Trastuzumab in Adjuvant Setting for Early Stage Breast Cancer, Öztop, İ., International Journal of Hematology and Oncology, 3(17):184-192

Park et al, 2015. Qualification and application of a liquid chromatography-quadrupole time-offlight mass spectrometric method for the determination of trastuzumab in rat plasma, Park, M.H., Lee, M.W., Shin, Y.G., Biomed. Chromatogr., 30(4):625-631.

Rebello and Hale, 2002. Pharmacokinetics of CAMPATH-1H:assay development and validation, Rebello P., Hale G., Journal of Immunological Methods, 260: 285-302

RXMediapharma ${ }^{\circledR}, 2019$. İnteraktif İlaç Bilgi Kaynağı, Prof. dr. Levent ÜSTÜNES

Selimoğlu et al, 2016. Yesterday, Today and the Future of Monoclonal Antibody Technology, Selimoğlu, S.M., Kasap, M., Akpınar, G., Karadenizli, A., J. of Health Sciences of Kocaeli University, $.2(1), 6-14$

Shimadzu, 2017. LCMS Bioanalysis of Antibody Drugs Using Fab-Selective Proteolysis nSMOL - Trastuzumab 
analysis -, Shimadzu Corporation, Application News, No. C145B

Şakalar et al., 2013. Kanser İmmün Terapi ve Monoklonal Antikorlar, Şakalar, Ç., İzgi, K., Canatan, H. F.Ü.Săg.Bil.Tıp Derg. 27 (2): 105 - 110

Sonuç and Sezgintürk, 2014. Ultrasensitive electrochemical detection of cancer associated biomarker HER3 based on anti-HER3 biosensor, Sonuç, M.N., Sezgintürk, M.K., Talanta, 120, 355361

Thermo, 2013. $\mathrm{NAb}^{\mathrm{TM}}$ Spin Kits, $0.2 \mathrm{~mL}$ for Antibody Purification, Thermo Scientific Instructions, Www.thermoscientific.com/pierce access date: 22.12.2018.

WHO, 2009. World Health Organization Expert Committee on Biological Standardization: Guidelines on Evaluation of Similar Biotherapeutic Products (2009); www.who.int/biologicals/areas/biologi cal therapeutics/ access date. 16.12.2018
Williams and Perry, 1985. A double determinant sandwich immunoassay for quantitation of serum monoclonal anti-I-A antibody, Williams, R., Perry, L.L., Journal of Immunological Methods, 85(2): 279-294.

www.ema.europa.eu, 2010. Guideline on the Investigation of Bioequivalence, www.ema.europa.eu/documents/scienti fic-guideline/guideline-investigationbioequivalence-rev1_en.pdf Access Date: 20.12.2018.

www.gabionline.net, 2018, Biosimilars of trastuzumab, http://www.gabionline.net/Biosimilars/ General/Biosimilars-of-trastuzumab, Access Date: 20.12.2018.

www.titck.gov.tr, 2008. https://www.titck.gov.tr/PortalAdmin/ Uploads/ UnitPageAttachment/c7idnsSQ.docx, access date: 19.12. 2018. 